\title{
Development and Application of Improved Long-Term Datasets of Surface Hydrology for Texas
}

\author{
Kyungtae Lee, ${ }^{1}$ Huilin Gao, ${ }^{1}$ Maoyi Huang, ${ }^{2}$ Justin Sheffield, ${ }^{3,4}$ and Xiaogang Shi ${ }^{5}$ \\ ${ }^{1}$ Department of Civil Engineering, Texas A\&M University, College Station, TX 77843, USA \\ ${ }^{2}$ Earth System Analysis and Modeling Group, Pacific Northwest National Laboratory, Richland, WA 99352, USA \\ ${ }^{3}$ Department of Civil and Environmental Engineering, Princeton University, Princeton, NJ 08544, USA \\ ${ }^{4}$ Geography and Environment, University of Southampton, Southampton SO17 1BJ, UK \\ ${ }^{5}$ Department of Civil Engineering, Xian Jiaotong-Liverpool University, Suzhou 215123, China
}

Correspondence should be addressed to Huilin Gao; hgao@civil.tamu.edu

Received 5 October 2016; Revised 31 January 2017; Accepted 8 February 2017; Published 6 March 2017

Academic Editor: Olga Zolina

Copyright ( 2017 Kyungtae Lee et al. This is an open access article distributed under the Creative Commons Attribution License, which permits unrestricted use, distribution, and reproduction in any medium, provided the original work is properly cited.

Freshwater availability and agricultural production are key factors for sustaining the fast growing population and economy in the state of Texas, which is the third largest state in terms of agricultural production in the United States. This paper describes a longterm (1918-2011) grid-based $\left(1 / 8^{\circ}\right)$ surface hydrological dataset for Texas at a daily time step based on simulations from the Variable Infiltration Capacity (VIC) hydrological model. The model was calibrated and validated against observed streamflow over 10 Texas river basins. The simulated soil moisture was also evaluated using in situ observations. Results suggest that there is a decreasing trend in precipitation and an increasing trend in temperature in most of the basins. Droughts and floods were reconstructed and analyzed. In particular, the spatially distributed severity and duration of major Texas droughts were compared to identify new characteristics. The modeled flood recurrence interval and the return period were also compared with observations. Results suggest the performance of extreme flood simulations needs further improvement. This dataset is expected to serve as a benchmark which may contribute to water resources management and to mitigating agricultural drought, especially in the context of understanding the effects of climate change on crop yield in Texas.

\section{Introduction}

Texas, the largest state in the contiguous United States (CONUS), contains a wide range of climate regimes from arid to subtropical humid [1]. The diverse climate range in Texas manifests itself as large spatial and temporal variations in precipitation and temperature. Due to these large spatial and temporal variations of rainfall and temperature, hydrologic extreme events (such as droughts and floods) have led to adverse conditions for agricultural production [2]. This is a pressing issue for Texas, which has the largest farm area and the highest livestock production among the 50 states. Overall, Texas ranks third with regard to agricultural production [3].

During the past century, Texas has experienced a number of major drought and flood events [4-7]. Among the weatherrelated disasters, drought ranks first in causing loss of life and second in causing property loss [5]. Drought in the
United States results in an estimated average annual damage of between 6 and 8 billion dollars $[8,9]$. As a slow-motion disaster, drought brings a series of calamities to Texas life including dust storms, crop failures, livestock losses, and economic crises. The recent record drought in 2011 left the state with 7.6 billion dollars in agricultural losses and with a multitude of dried up lakes and rivers [10]. Unlike droughts which persist for months and longer, floods are usually triggered by heavy rainfall during a short period of time [11]. Flooding depends on a number of factors such as the magnitude and intensity of rainfall, antecedent soil moisture conditions, topography of the affected landscape, soil type, and land use [12, 13]. Between 1985 and 2014 flooding caused an average of 82 deaths and $\$ 7.9$ billion in property damage annually across the US [14]. With 840 lives lost between 1959 and 2008, Texas has the highest incidence of flood related fatalities among all 50 states [15]. Texas is also the only state 
that has reported flood related fatalities in every single year during that same period [16].

While battling these extreme events, Texas has become a water deficient state where the demands for fresh water have been exacerbated by a rapidly growing population. These water issues are further challenged by climatic and land use changes, both of which may alter the natural hydrologic processes. With a changing climate, hydrologic extremes are projected to become more frequent, more severe, and more uncertain [17-19]. Additionally, the increasing portion of impervious land cover (due to urbanization) has a direct effect on elevating flood peaks [20]. Due to the importance of water resources for Texas and its vulnerability to waterrelated extreme events, it is necessary to understand how future changes may impact Texas' water resources and (river system) water budgets [21].

In this context, comprehensive and reliable hydrologic datasets which can support the analysis of historical hydrologic extreme events are essential. Specifically, high quality datasets can be used to identify the onset and demise of droughts and floods, along with the multiple feedback processes associated with hydrological extremes [11]. Furthermore, such datasets can serve as a benchmark to evaluate future extreme events and to prevent record setting disasters in advance (through combining effective water resources management measures with model predictions).

With the enhanced computational capabilities, a high volume of hydrological datasets have recently been generated (and released) for studying droughts and floods. For instance, the North American Land Data Assimilation System-2 (NLDAS-2; [22]) includes long-term (1979-present) simulations of the surface hydrology for the contiguous United States at $1 / 8^{\circ}$ resolution. This dataset has been used for providing long-term records of water budget terms, for analyzing historic droughts, and for providing the basis for seasonal drought prediction [23-25]. These types of datasets have also been widely used in regional assessments of climate change impacts on surface hydrology, such as in a set of studies focused on the Colorado River basin [26, 27]. Such modeled hydrologic datasets have strong advantages over traditional observation based datasets, whose availability is limited in time and space. For example, in situ observations are often available only at point locations, or over areas much smaller than the model spatial resolution. Comparisons are therefore restricted to the temporal and spatial scales resolved by the model [28].

Although many of the above-mentioned hydrologic datasets contain gridded, long-term modeled results over the entire state of Texas, the data quality is often inadequate to support decision making. Typically, only a very small number of the Texas river basins (only one or two of them) have been calibrated against observed streamflow (e.g., $[28,29]$ ). The results of a study by Oubeidillah et al. [30], which calibrated for 2107 hydrologic subbasins (8-digit hydrologic units, HUC8s) over the entire CONUS, show that the NashSutcliffe values for most Texas basins are negative. Without a well-tested reliable dataset, all analyses will be at risk for providing misleading conclusions and recommendations. Therefore, there is a strong need for effectively constraining the quality of hydrologic model simulation results through calibration over each individual river basin in Texas.

Driven by the meteorological forcings of Livneh et al. ([29]; hereafter L13), we hereby provide a calibrated and validated hydrological dataset for 10 major Texas river basins. The dataset is deemed high quality because of its relatively high spatial $\left(1 / 8^{\circ}\right)$ and temporal (daily) resolutions and its evaluated skill compared to observed hydrological variables. The dataset includes evapotranspiration, runoff, and soil moisture records from 1918 to 2011. The L13 meteorological forcings are available from 1915 to 2011, but we used the first three years for model spin-up (and then analyzed from 1918 onward). The dataset generated from this study was utilized to fulfill two research objectives: (1) to evaluate the impacts of a changing climate on the water budget terms and (2) to reveal new perspectives about hydrologic extreme events (such as droughts and floods) which cannot be assessed using traditional observations. This study is organized as follows: the data and methods are presented in Section 2, where the calibration of the soil parameters and the validation of the simulated results are described. The quality of the simulated soil moisture is evaluated against observed soil moisture. In Section 3, the differences in water budget terms are studied by comparing two periods: 1918-1959 (Period 1) and 19602011 (Period 2). Historical drought (severity and duration) and flood (recurrence interval and return period) events are investigated based on simulated hydrologic variables. We also compare the annual cycle of the water budget at each river basin between the two historical periods. Finally, discussion and conclusions are presented in Section 4.

\section{Data and Methodology}

2.1. Study Area. This study focuses on the Texas Gulf Region, located in southern central North America $\left(25-34^{\circ} \mathrm{N}, 93-\right.$ $103^{\circ} \mathrm{W}$ ), which has a total area of $343,100 \mathrm{~km}^{2}$. The region includes 10 major river basins (Figure 1) and covers five climate zones (from arid to subtropical humid). The domain contains geographical properties varying from dessert (far west Texas) to mountainous (Guadalupe Range) regions [31]. The diverse climate in Texas manifests itself as large spatial and temporal variations in precipitation and temperature. The annual mean precipitation in Southeast Texas is more than $1400 \mathrm{~mm}$, while Northwest Texas only receives about $400 \mathrm{~mm}$ [32]. The annual mean temperature varies greatly with latitude from north to south. According to Bomar [33], the average annual temperature (1961-1990) in the northern portion of the Texas High Plains is $13.2^{\circ} \mathrm{C}$, while it is $23.3^{\circ} \mathrm{C}$ in Southern Texas. While most west Texas rivers flow for only part of the year (due to a lack of precipitation), East Texas rivers flow year-round benefiting from a subtropical climate [34].

With an annual economic revenue of $\$ 100$ billion, agriculture is very important in Texas. A total of $528,000 \mathrm{~km}^{2}$ is occupied by farms and ranches. About $76 \%$ of Texas surface area is occupied by farms and ranches, and $22 \%$ of this is crop land. For the crop land portion, about $57 \%$ is harvested, $10 \%$ is grassland, and 33\% is either not harvested or fails to produce 


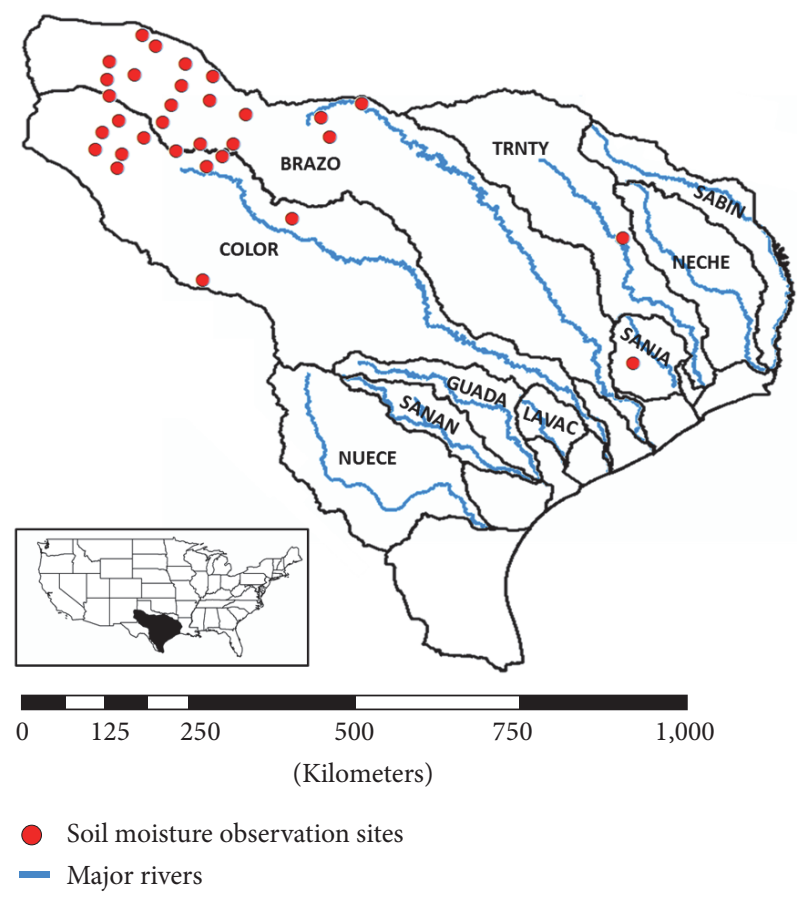

FIGURE 1: Location of the ten river basins and soil moisture observation sites used in this study.

crops [35]. The soil types in Texas range from clay to sand, with more than 1,300 different varieties of soil.

2.2. VIC Model. A semidistributed macro scale hydrological model, the Variable Infiltration Capacity (VIC) model [36], was used to generate the long-term hydrologic budget in this study. The VIC model has been widely utilized for assessing water resources, land-atmosphere interactions, and the overall hydrological budget (and its responses to weather and climate) over many river basins around the world [28, 37-41]. In the Jinghe basin, located in Northwest China, an assessment of the river system changes under both a changing climate and human activities was implemented using VIC modeled streamflow [42]. The VIC model was also employed to generate a forecast of soil moisture, runoff, and streamflow for the Yellow River in China [43]. VIC simulated soil moisture and runoff have made significant contributions to drought studies [44-49]. The VIC model has been well adopted for continental to global scale drought monitoring and forecasting using soil moisture and streamflow [50, 51]. Soil moisture, on one hand, is a critical variable for quantifying drought severity and extent; but on the other hand, it is typically not observed on a large scale over a long period. Therefore, soil moisture simulated by hydrologic models-such as the VIC model-may serve as the best alternative (to observations) at regional to global scales [28, $46,52,53]$.

The VIC model parameters can be classified into two groups, those that are prescribed and those that are calibrated. In this study, the soil and vegetation parameters that do not require calibration were adopted from the NLDAS-2 parameters at $1 / 8^{\circ}$ resolution [54]. The model was used to simulate the water and energy budgets, with the major hydrologic flux terms (e.g., evapotranspiration) and the state variables (e.g., soil moisture) simulated at a daily time step. The VIC modeled surface runoff and base flow at each grid cell were then routed through a Digital Elevation Model (DEM) based river network to generate streamflow estimations for each basin [55].

2.3. Meteorological Forcings. The observation based meteorological daily forcings from 1915 to 2011 were adopted from the L13 dataset to drive the VIC model. The grid-based L13 dataset includes four meteorological variables: precipitation, wind speed, and daily minimum and maximum temperature. The precipitation and temperature observations were provided by National Climatic Data Center (NCDC) and Cooperative Observer (COOP) stations. The Synergraphic Mapping System (SYMAP) algorithm [56] was employed to generate the gridded temperature and precipitation at $1 / 16^{\circ}$ resolution from the point data. The Parameter-Elevation Regressions on Independent Slopes Model (PRISM) was then used to match the long-term mean of the gridded precipitation data, which was scaled on a monthly basis [57]. Wind speed values, obtained from the National Centers for Environmental Prediction-National Center for Atmospheric Research (NCEP-NCAR) reanalysis [58], were linearly interpolated from $1.9^{\circ}$ resolution (approximately) to $1 / 8^{\circ}$ resolution. To match the spatial resolution of the VIC model parameters, the $1 / 16^{\circ}$ forcings from L13 were rescaled up to $1 / 8^{\circ}$ using the nearest-neighbor interpolation method.

2.4. Model Calibration. An automated optimization technique, Multiobjective Complex evolution (MOCOM-UA, [59]), was employed to calibrate the VIC model over the 10 major rivers in Texas. During the calibration process, the mean absolute error (MAE) and the Nash-Sutcliff coefficient [60] were used as the objective functions to minimize the difference between the simulated and observed streamflow. The monthly streamflow observations at the US Geological Survey (USGS) stations closest to the river outlets were used for both calibration and validation purposes (Table 1).

The calibration aimed to find the best soil parameter values for minimizing the difference between observed and simulated monthly streamflow over the calibration period (1960-1985). Six VIC soil parameters were selected for calibration based on sensitivity analysis [61], including the variable infiltration curve parameter $\left(b_{\text {inf }}\right)$, the exponent of the Brooks-Corey drainage equation (exp), the thickness of soil layers 2 and $3\left(D_{2}\right.$, and $\left.D_{3}\right)$, the fraction of the maximum velocity of base flow at which nonlinear base flow begins $\left(D_{s}\right)$, and the fraction of maximum soil moisture above which nonlinear base flow occurs $\left(W_{s}\right)$. The calibration involves setting an identical soil parameter set for each basin to find the best combination of the six parameters. Although the calibration period is about $0.3^{\circ} \mathrm{C}$ cooler than the annual temperature over the entire period, sensitivity test results (not shown) suggest that the temperature impacts on streamflow 
TABLE 1: Ten river basins and streamflow gauge stations.

\begin{tabular}{|c|c|c|c|c|c|c|}
\hline Name & Abbreviation & USGS station & Latitude $(\mathrm{N})$ & Longitude (W) & Basin area $\left(\mathrm{km}^{2}\right)$ & Period \\
\hline Sabine & SABIN & 08030500 & $30^{\circ} 18^{\prime} 13^{\prime \prime}$ & $93^{\circ} 44^{\prime} 37^{\prime \prime}$ & 19,617 & 1924-2016 \\
\hline Neches & NECHE & 08041000 & $30^{\circ} 21^{\prime} 20^{\prime \prime}$ & $94^{\circ} 05^{\prime} 35^{\prime \prime}$ & 25,752 & $1922-2016$ \\
\hline Trinity & TRNTY & 08066250 & $30^{\circ} 34^{\prime} 19^{\prime \prime}$ & $94^{\circ} 56^{\prime} 55^{\prime \prime}$ & 46,418 & 1965-2016 \\
\hline Brazos & BRAZO & 08111500 & $30^{\circ} 07^{\prime} 44^{\prime \prime}$ & $96^{\circ} 11^{\prime} 15^{\prime \prime}$ & 111,077 & 1938-2016 \\
\hline Colorado & COLOR & 08162000 & $29^{\circ} 18^{\prime} 32^{\prime \prime}$ & $96^{\circ} 06^{\prime} 13^{\prime \prime}$ & 102,172 & $1938-2016$ \\
\hline Guadalupe & GUADA & 08175800 & $29^{\circ} 05^{\prime} 25^{\prime \prime}$ & $97^{\circ} 19^{\prime} 46^{\prime \prime}$ & 15,426 & 1964-2016 \\
\hline San Antonio & SANAN & 08188500 & $28^{\circ} 38^{\prime} 57^{\prime \prime}$ & $97^{\circ} 23^{\prime} 05^{\prime \prime}$ & 10,831 & 1924-2016 \\
\hline Nueces & NUECE & 08211000 & $28^{\circ} 02^{\prime} 17^{\prime \prime}$ & $97^{\circ} 51^{\prime} 36^{\prime \prime}$ & 43,276 & 1939-2016 \\
\hline San Jacinto & SANJA & 08068000 & $30^{\circ} 14^{\prime} 40^{\prime \prime}$ & $95^{\circ} 27^{\prime} 25^{\prime \prime}$ & 10,199 & 1924-2016 \\
\hline Lavaca & LAVAC & 08164000 & $28^{\circ} 57^{\prime} 35^{\prime \prime}$ & $96^{\circ} 41^{\prime} 10^{\prime \prime}$ & 5,985 & 1938-2016 \\
\hline
\end{tabular}
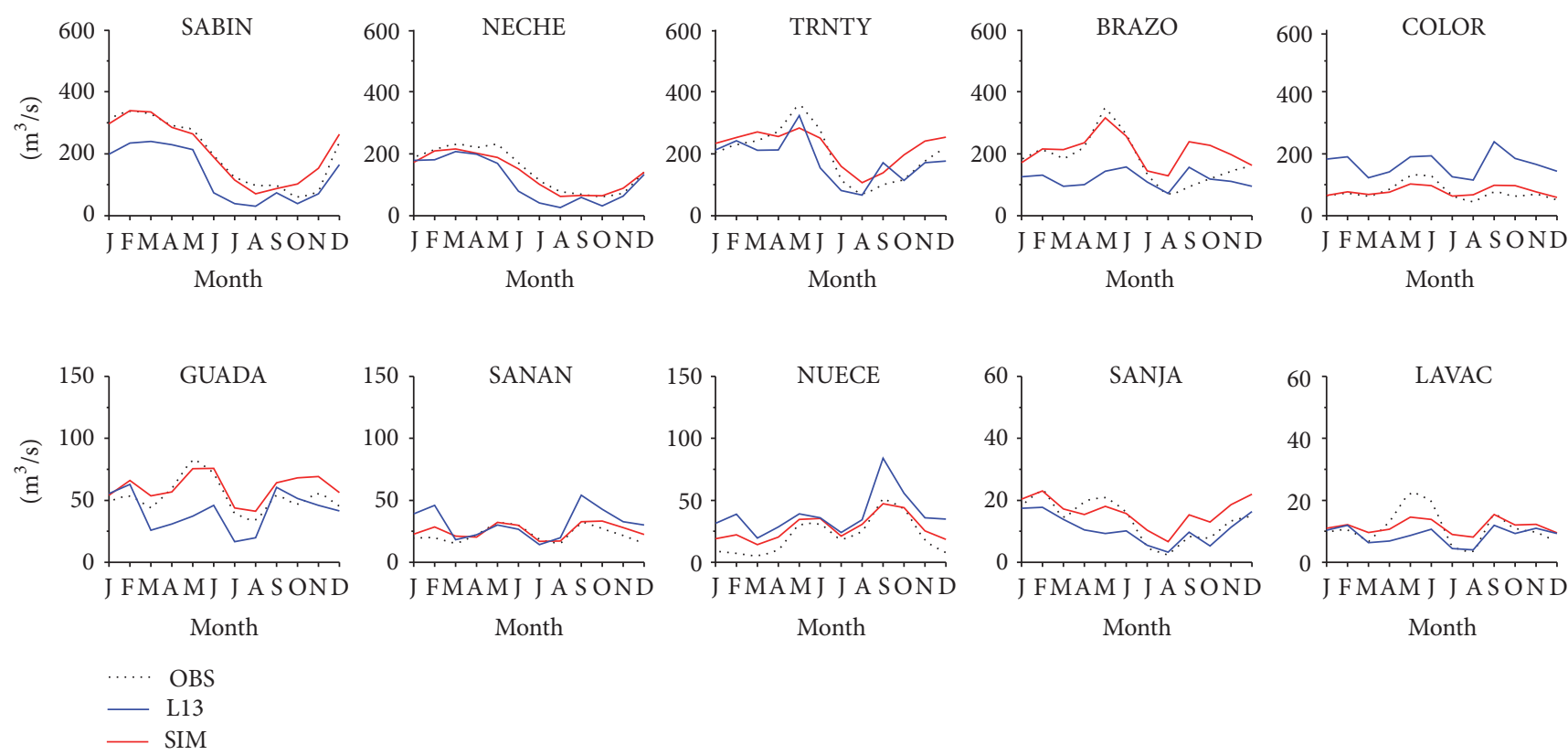

FIgURE 2: Monthly observed (OBS), L13, and calibrated (SIM) streamflow (1960-1985).

in Texas river basins are ignorable. This can be explained by the fact that Texas is water limited and rainfall typically occurs at large rates over short periods-which makes soil moisture and streamflow insensitive to small variations of annual temperature.

Figure 2 compares the annual cycle of the calibrated monthly streamflow with observations over the 10 major Texas river basins, and Table 2 lists the statistics of the calibration and validation results. Overall, the calibrated results are improved over the original VIC simulations in L13. The Sabine and Neches Basins, where there is ample rainfall and runoff, have the best calibration results among all of the basins studied. The Brazos River Basin, which has the largest drainage area, does not match the observations well during the low flow seasons (August-November). A possible reason for this is that the Brazos River is highly regulated by many reservoirs, which may have altered the streamflow patterns significantly. To test this, the VIC simulated streamflow was compared with observations during the prereservoir era and the postreservoir era. Because most reservoirs on the Brazos were built after the 1960s, results from 1939 to 1960 were considered prereservoir (as observed streamflow record started in 1939) and results from 1961 to 2011 were considered postreservoir. It was found that the $R^{2}$ and NSE values are 0.88 and 0.64 prereservoir, while the values are 0.84 and 0.62 postreservoir. Given that VIC simulated flows are naturalized flows (i.e., no reservoir effects are considered), such discrepancy before and after reservoir construction is unavoidable. Regardless, the error statistics for the Brazos have improved the most (of all the basins in the study). Although the calibrated streamflow over the Nueces does not outperform the L13 results (in terms of all four of the statistical variables), its annual cycle and MAE have shown much better agreement with the observations than 
TABLE 2: The statistics of calibrated and validated monthly flows.

\begin{tabular}{|c|c|c|c|c|c|c|}
\hline Basin & Conditions & Period & $R^{2}$ & NSE & MAE/OBS & RMSE/OBS \\
\hline \multirow{3}{*}{ SABIN } & L13 & 1960-1985 & 0.87 & 0.69 & 0.27 & 0.55 \\
\hline & Calibration & 1960-1985 & 0.88 & 0.76 & 0.03 & 0.48 \\
\hline & Validation & 1925-2011 & 0.88 & 0.76 & 0.05 & 0.50 \\
\hline \multirow{3}{*}{ NECHE } & L13 & 1960-1985 & 0.81 & 0.57 & 0.18 & 0.65 \\
\hline & Calibration & 1960-1985 & 0.91 & 0.78 & 0.07 & 0.47 \\
\hline & Validation & 1922-2011 & 0.87 & 0.70 & 0.02 & 0.59 \\
\hline \multirow{3}{*}{ TRNTY } & L13 & 1960-1985 & 0.83 & 0.68 & 0.05 & 0.60 \\
\hline & Calibration & 1960-1985 & 0.87 & 0.70 & 0.11 & 0.58 \\
\hline & Validation & 1966-2011 & 0.88 & 0.70 & 0.11 & 0.63 \\
\hline \multirow{3}{*}{ BRAZO } & L13 & 1960-1985 & 0.62 & 0.23 & 0.35 & 0.99 \\
\hline & Calibration & 1960-1985 & 0.86 & 0.70 & 0.15 & 0.62 \\
\hline & Validation & 1939-2011 & 0.85 & 0.63 & 0.14 & 0.77 \\
\hline \multirow{3}{*}{ COLOR } & L13 & 1960-1985 & 0.61 & 0.46 & 0.76 & 1.20 \\
\hline & Calibration & 1960-1985 & 0.77 & 0.57 & 0.04 & 0.65 \\
\hline & Validation & 1939-2011 & 0.75 & 0.51 & 0.10 & 0.91 \\
\hline \multirow{3}{*}{ GUADA } & L13 & 1960-1985 & 0.77 & 0.52 & 0.26 & 0.71 \\
\hline & Calibration & 1960-1985 & 0.84 & 0.69 & 0.14 & 0.58 \\
\hline & Validation & 1965-2011 & 0.86 & 0.71 & 0.14 & 0.69 \\
\hline \multirow{3}{*}{ SANAN } & L13 & 1960-1985 & 0.83 & 0.59 & 0.34 & 0.85 \\
\hline & Calibration & 1960-1985 & 0.83 & 0.64 & 0.13 & 0.76 \\
\hline & Validation & 1940-2011 & 0.82 & 0.67 & 0.16 & 0.89 \\
\hline \multirow{3}{*}{ NUECE } & L13 & 1960-1985 & 0.86 & 0.62 & 0.85 & 1.66 \\
\hline & Calibration & 1960-1985 & 0.78 & 0.50 & 0.30 & 1.93 \\
\hline & Validation & 1940-2011 & 0.72 & 0.45 & 0.44 & 1.89 \\
\hline \multirow{3}{*}{ SANJA } & L13 & 1960-1985 & 0.75 & 0.53 & 0.08 & 0.95 \\
\hline & Calibration & 1960-1985 & 0.87 & 0.71 & 0.06 & 0.75 \\
\hline & Validation & $1940-2011$ & 0.81 & 0.62 & 0.14 & 0.98 \\
\hline \multirow{3}{*}{ LAVAC } & L13 & 1960-1985 & 0.82 & 0.54 & 0.22 & 1.11 \\
\hline & Calibration & 1960-1985 & 0.85 & 0.56 & 0.03 & 1.11 \\
\hline & Validation & 1939-2011 & 0.81 & 0.47 & 0.01 & 1.44 \\
\hline
\end{tabular}

the L13 dataset does. Indeed, the calibration has successfully eliminated the overestimation in the September and October (shown by the L13) dataset over the Nueces Basin.

2.5. Model Validation. The performance of the VIC simulations was evaluated in terms of streamflow and soil moisture results. The former is the most commonly adopted approach for testing water budget terms as a whole. The latter is of special importance since soil moisture was used to quantify droughts in this study. Such comprehensive comparisons allow us to sufficiently test the robustness of this dataset.

Firstly, the streamflow values simulated using the optimally calibrated parameter sets were validated over each basin based on the availability of USGS streamflow observations. Overall, the validation results (in Table 2) are consistent with the calibration across all basins. The $R^{2}$ and NSE values for the calibration period range from $0.77 \sim 0.91$ and $0.50 \sim$ 0.78 , while the $R^{2}$ and NSE for the validation period range from $0.72 \sim 0.88$ and $0.45 \sim 0.76$. The best performance (with regard to validation) is found at the Sabine and Neches River basins, while the worst is at the Nueces River Basin.

Secondly, the modeled soil moisture was compared with in situ observations. The quality controlled observational soil moisture data from the North American Soil Moisture Database (NASMD) [62] was adopted for validating the VIC simulated soil moisture. Currently, NASMD includes data from 27 observational networks and 1800 sites across North America. Here, NASMD soil moisture observations from 31 sites located in Texas (Figure 1) were used to evaluate the VIC model simulated soil moisture products. In this study, soil moisture was simulated at $1 / 8^{\circ}$ resolution over three soil layers occurring at depths of $0-10 \mathrm{~cm}, 10-40 \mathrm{~cm}$, and $40-100 \mathrm{~cm}$, respectively. The NASMD in situ observations were collected at $5 \mathrm{~cm}$ and $25 \mathrm{~cm}$ depths. The VIC soil moisture outputs at the top layer were validated by the top layer NASMD in situ observations, and the VIC outputs at the middle layer were compared with the observations made at $25 \mathrm{~cm}$. Considering the different scales of the point observations and the gridded simulations, the averaged soil moisture values 
TABLE 3: Validation results for the simulated soil moisture.

\begin{tabular}{|c|c|c|c|c|}
\hline \multirow{2}{*}{$\begin{array}{l}\text { Error metrics } \\
\text { (daily, 2003-2010) }\end{array}$} & \multicolumn{2}{|c|}{ OBS $5 \mathrm{~cm}$ (top layer) } & \multicolumn{2}{|c|}{ OBS $25 \mathrm{~cm}$ (second layer) } \\
\hline & SIM $^{*}$ & L13 & SIM $^{*}$ & L13 \\
\hline$R^{2}$ & 0.75 & 0.73 & 0.75 & 0.71 \\
\hline $\operatorname{RMSE}\left(\mathrm{m}^{3} \mathrm{~m}^{-3}\right)$ & 0.0349 & 0.0421 & 0.0206 & 0.0285 \\
\hline $\operatorname{Bias}\left(\mathrm{m}^{3} \mathrm{~m}^{-3}\right)$ & 0.0313 & 0.0395 & -0.0146 & -0.0185 \\
\hline $\operatorname{Bias}_{R}(\%)$ & 16.70 & 21.13 & -6.42 & -8.11 \\
\hline
\end{tabular}

${ }^{*}$ Simulated results from this study.
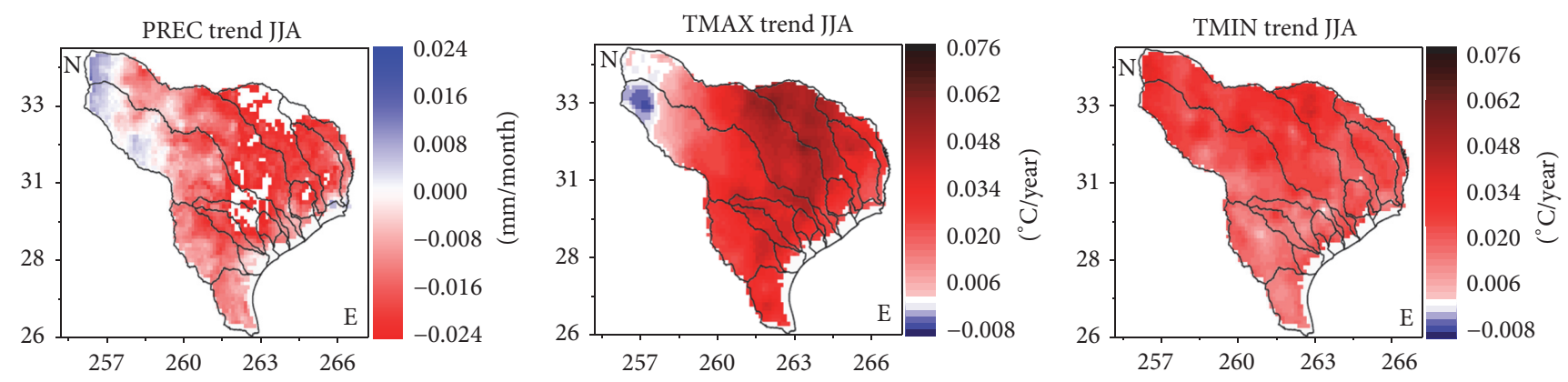

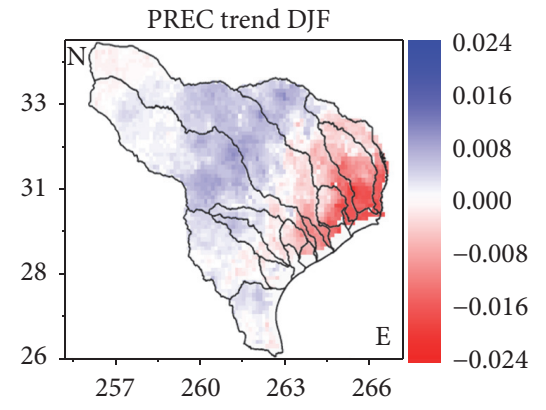

(a)

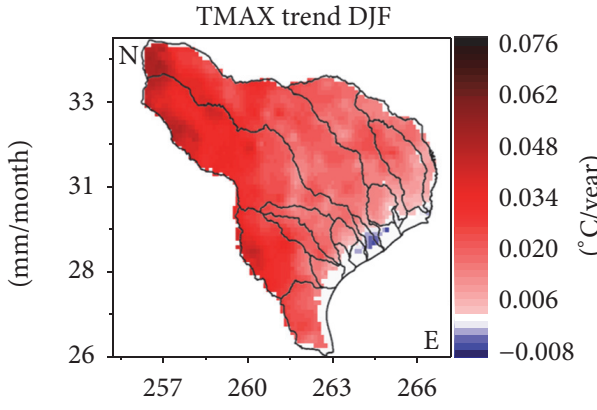

(b)

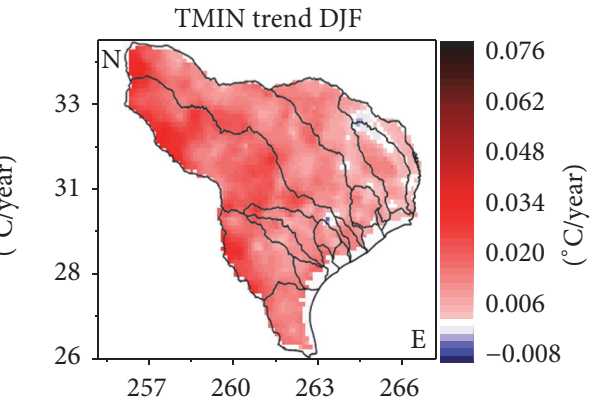

(c)

FiguRE 3: Summer (June-August) and winter (December-February) precipitation (a), maximum temperature (b), and minimum temperature (c) trend.

from the 31 reporting NASMD sites were compared with the averaged VIC soil moisture values from the 31 grids overlaying those sites. This spatial averaging approach has been commonly adopted for evaluating a remotely sensed (or modeled) soil moisture product using in situ observations $[62,63]$.

Statistical metrics-including the Root Mean Squared Error (RMSE), the Bias, and the Bias ratio-were used to determine the errors associated with the simulated soil moisture. Table 3 suggests that the soil moisture error metrics have been improved at both layers when compared with the L13 dataset.

\section{Results and Applications}

In this section, the VIC simulated hydrologic records are used in three applications: (1) investigating the changes in the climate and hydrologic cycles between two historical periods; (2) characterizing historical drought events using reconstructed soil moisture information; and (3) exploring the capability of quantifying both peak flows and the recurrence intervals of flood events from simulated peak flows.

3.1. Changes of the Hydrologic Cycle. Over the entire domain, we first examined the trends of the gridded meteorological forcings for summer and winter (Figure 3). Summer (JuneJuly-August, JJA) precipitation decreased across the entire state of Texas, with the exception of the northwest corner. In contrast, winter (December-January-February, DJF) precipitation increased in the semiarid mid-Texas and west Texas regions but decreased in the humid east Texas region. The maximum temperature increased in most of Texas during both seasons-with summer being the largest in magnitude. The minimum temperature also increased in both summer and winter. Compared to the maximum temperature trend, the changes with minimum temperature are relatively small (but are more uniform).

The annual cycles of the water budget terms over the two historical periods were then compared over each basin (Figure 4). Most Texas river basins are characterized by 

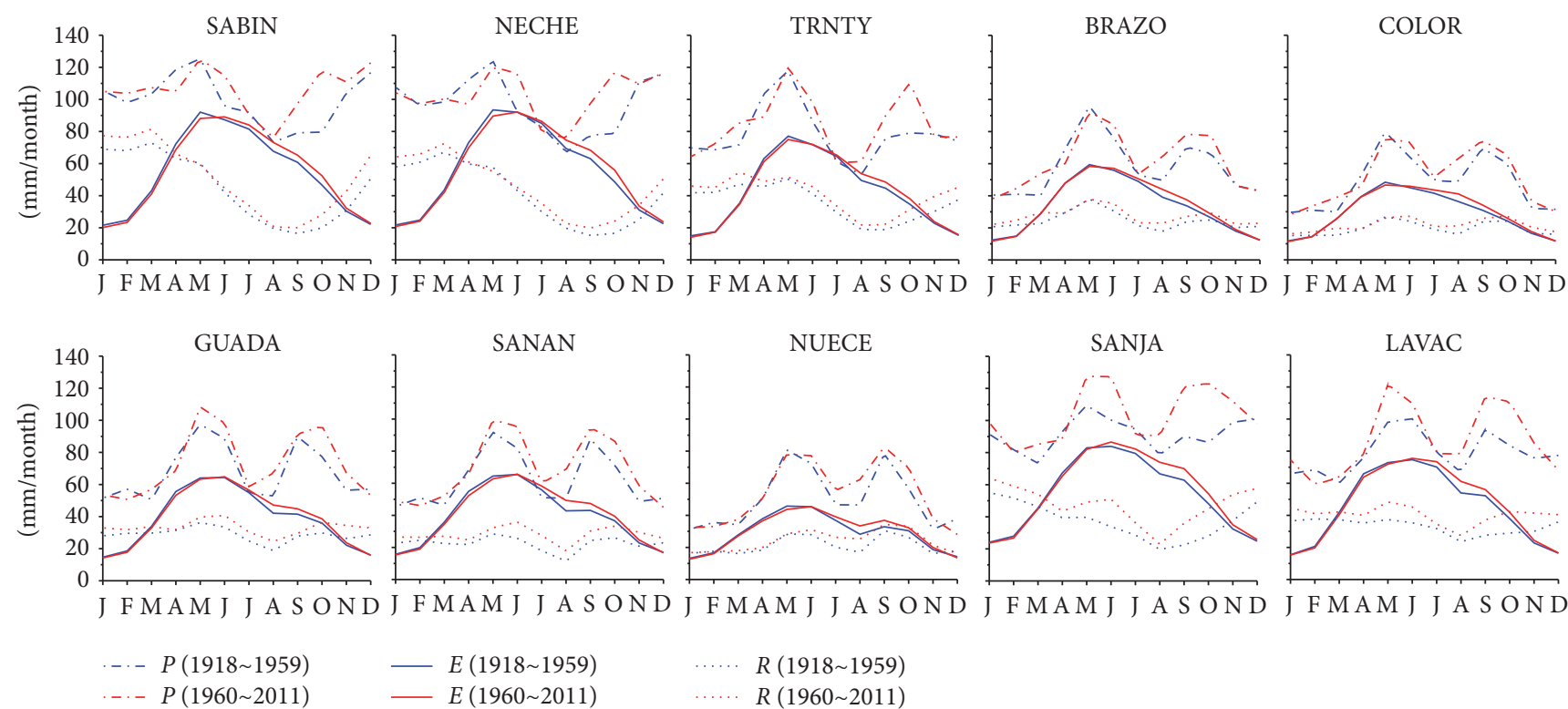

-. $-P(1960 \sim 2011)$

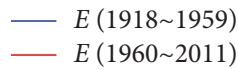

$R(1918 \sim 1959)$

$R(1960 \sim 2011)$

FIgURE 4: Annual cycle of surface hydrology $(P=$ precipitation, $E=$ evapotranspiration, and $R=$ runoff + base flow $)$.

two precipitation peaks (one in the spring and one in the fall), with very little rainfall during the summer. From Period 1 to Period 2, precipitation has increased across all of the basins studied, with the largest changes occurring during the peak months. Among these basins, a notable increase of precipitation is captured in the San Jacinto and Lavaca basins during Period 2. The Brazos and Colorado River Basins, which are the two largest basins, have less precipitation and much smaller runoff than the other basins. Evapotranspiration has only one peak, which occurs in May due to the coinciding high soil moisture and the warm temperature. With regard to runoff, the smallest values are found in August and September. The Sabine and Neches both generate more winter runoff than the other basins. Driven by precipitation changes, runoff also increases during Period 2. As explained earlier about the impact of the temperature trend, the warming in Period 2 has little effect on altering runoff. Texas is thus prone to both droughts and floods as a consequence of the large seasonal variations in the water budget terms.

3.2. Drought Analysis. From 1918 to 2011, there were five remarkably severe droughts in Texas. The 1925 drought set record high temperatures and record low rainfall. From 1930 to 1936, the famous Dust Bowl drought led to tremendous economic and agricultural losses. The catastrophic 1950s drought lasted for seven years (1950-1957) and subsequently has been considered the worst drought event in Texas. In 1971, some portions of North Texas received only one inch $(2.54 \mathrm{~cm})$ of rainfall during the entire year. As a result, this severe drought cost $\$ 100$ million worth of crop losses (mainly with wheat and cotton) and killed over 100,000 cattle (due to the drying up of grasslands, and thirst from high temperatures). In 2011, the region experienced the hottest and driest one-year period ever recorded, with a loss of $\$ 7.62$ billion in the agriculture sector alone [10, 64, 65].

In this section, the hydrologic records provided by the VIC simulations are used to offer new perspectives on these drought events, particularly focusing on agricultural drought. Figure 5 shows the drought outlook over the entire domain using the time series values of precipitation, temperature, soil moisture anomaly, runoff/precipitation ratio $(R / P)$, drought severity, and drought areal extent.

As a function of both precipitation and temperature, the Palmer Drought Severity Index (PDSI) is a very commonly used index for detecting meteorological drought [66, 67]. However, whether PDSI represents soil moisture conditions is still debatable. A study by Dai et al. [68] concluded that PDSI does not reflect soil moisture conditions and therefore is not a good measure of agricultural drought; but others have found that the PDSI correlates quite well with the observed and modeled monthly soil moisture contents over a large scale [69]. The main advantage in using the soil moisture based index to monitor agricultural drought is that soil moisture deficit is affected by both meteorological conditions (i.e., precipitation and temperature) and by soil/vegetation types. Unlike PDSI, this index can provide soil moisture information that is directly useful for water management under drought conditions. The disadvantage of this approach is that accurate soil moisture data are hard to acquire. On the one hand, in situ measurements are spatially and temporally limited, making it challenging for monitoring drought consistently at a large scale. On the other hand, modeled soil moisture datasets are typically not systematically evaluated. However, by using the modeled soil moisture, which has been validated by in situ measurements, these limitations are overcome in this study.

In this study, an agricultural drought is defined using the 10th percentile of monthly soil moisture in a grid cell 

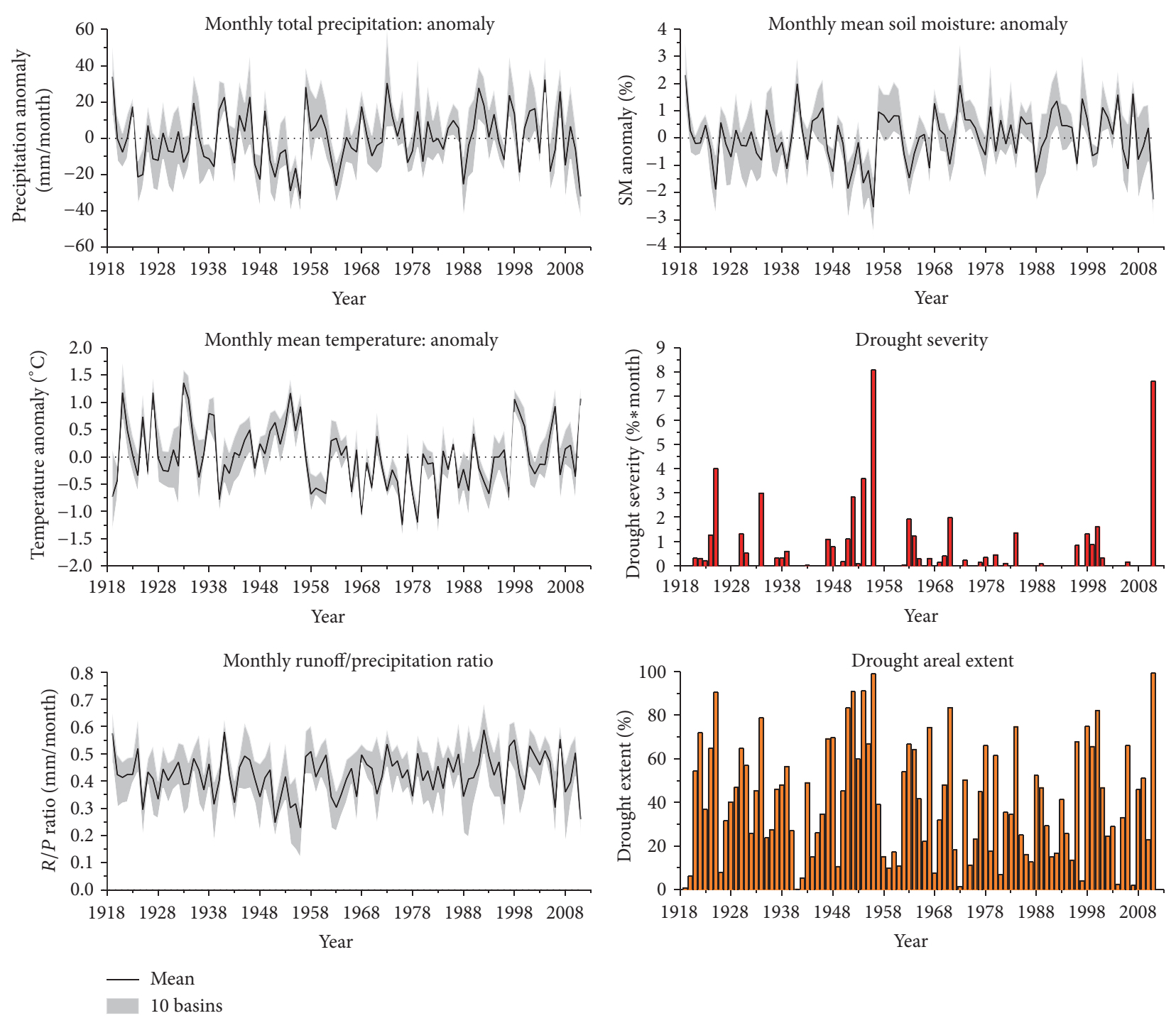

Figure 5: 20th century Texas drought outlook (climate, surface hydrology, drought severity, and drought areal extent).

as a threshold [70]. The drought severity is calculated as the product of the monthly soil moisture deficit (\%) and the duration (counting the number of months that experience drought). The drought extent is calculated for each year, represented by the percentage of grid cells that experience at least one month of drought. Both the 1956 and 2011 severe droughts stand out clearly, mainly because precipitation, the $R / P$ ratio, and the soil moisture anomaly were all at record lows and temperature set record highs. Overall, the five most severe droughts are well captured by the simulated drought outlook.

Figure 6 shows the spatial patterns of drought severity and duration for the five selected historical drought events (in the order of severity: 1956, 2011, 1925, 1934, and 1971). The severity and duration maps tend to share a similar spatial pattern. The 1956 drought was the most catastrophic due to its severity and long duration. The 2011 drought was the most severe single year drought, while the 1925 drought was characterized by its long duration. The region with the largest drought severity is centered on eastern Texas in 1925, while the highest impact drought is the one in the Trinity River basin in 1934. Drought is hardly detected in the Upper Colorado basin and in southern Texas during 1934. The drought in 1971 was the least severe among these five events, with the area affected located in the San Antonio and lower Colorado River basins. The maximum drought durations are associated with the 1956 and 1925 droughts. According to the analysis of the five severe drought events, the Colorado River basin and the region along the Gulf coast are more vulnerable to drought than the other areas.

3.3. Flood Analysis. An annual maximum series analysis (AMS; [20]) was performed to investigate the magnitude and recurrence interval of flood events. The AMS of a given year is the maximum daily streamflow value that occurred in that year. In this study, there are 94 AMS values during the entire simulation period (1918-2011) for each basin. Two sets of AMS values were calculated for the 10 basins based 

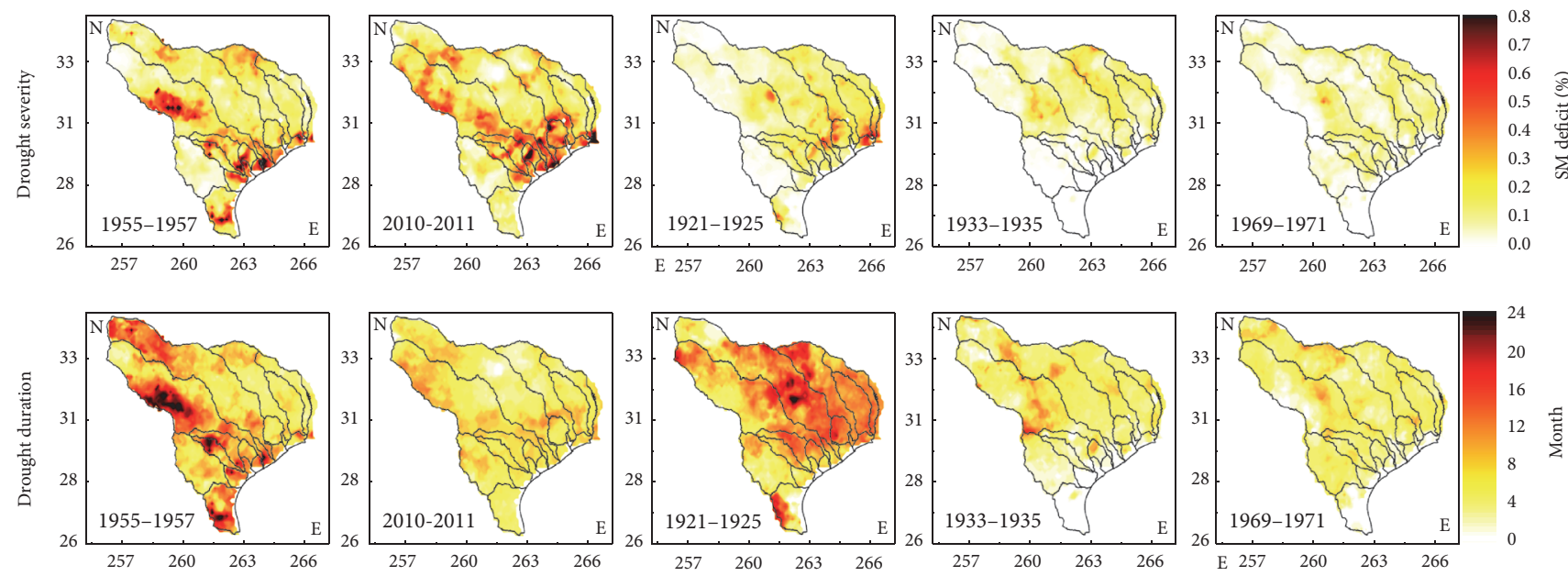

FIGURE 6: Reconstructed drought severity and duration.

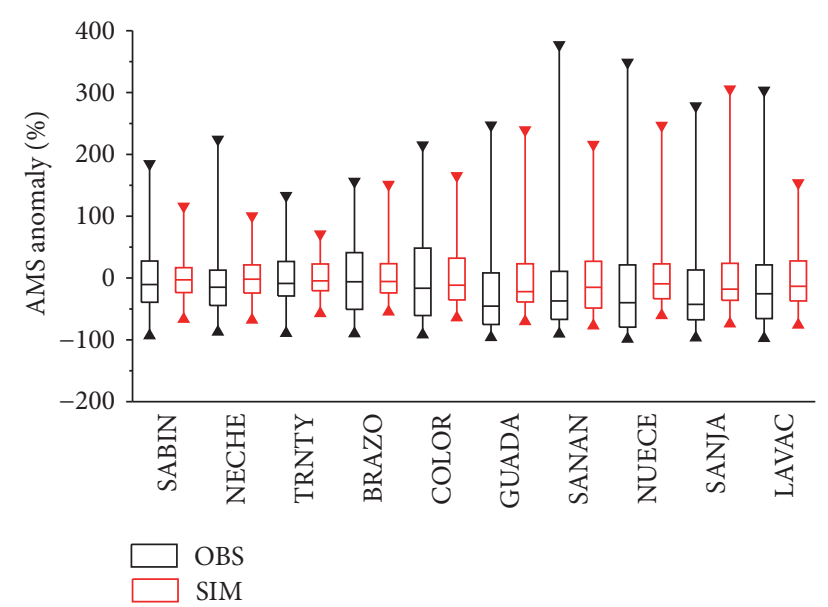

Figure 7: Annual maximum streamflow (AMS) anomaly (\%) during the period from 1918 to 2011.

on daily streamflow from USGS observations and from VIC simulations.

Figure 7 shows the comparison of the relative AMS anomaly (in terms of percentage) between observations and model simulations. The relative AMS anomaly is calculated by dividing the anomaly value with the mean AMS. The mean AMS for a basin of interest is the averaged value of those 94 AMS values. We used the relative AMS anomaly to make the basins comparable, because each basin has its own range of AMS. Overall, the simulated AMS values are in agreement with the observed ones. The median and the minimum values of the simulated AMS anomaly are larger than the observations-but the range of the simulated AMS anomalies is smaller than its observed counterpart in most cases. The differences between the modeled and observed AMS anomalies are mainly attributed to two factors: first, the model was calibrated using criteria based on monthly streamflow, while the AMS anomalies are statistics from daily data. Second, the gridded precipitation forcings usually underestimate the extreme values, especially over regions like Texas where the rate of rainfall can be very large over a short period of time [71, 72]. The San Antonio, Nueces, and Lavaca river basins (where the basin size, in each case, is relatively small compared to other basins) tend to have larger interannual variability in AMS. The five river basins with the largest AMS anomalies are the San Antonio, Nueces, Lavaca, San Jacinto, and Guadalupe. These basins are relatively small in size, and they are primarily located along the coast of central Texas. Driven by large seasonal and interannual precipitation variations, the AMS anomalies are therefore substantial. These basins are very prone to floods-including hurricane floods, due to their vicinity to the coast. The simulated maximum AMS results best agree with observations over the Guadalupe and San Jacinto River basins.

With regard to flood analysis, it is essential to understand the relationship between the magnitude of peak events and their frequency of occurrence (in terms of return period). The concept of return period $T$ is used to describe the likelihood of occurrences [73]. An extreme event is defined as occurring when a random variable $X$ is greater than or equal to a certain level $x_{T}$. The recurrence interval $\sigma$ is the time between occurrences of $X \geq x_{T}$. Here we define $x_{T}$ as the 90th percentile, 80th percentile, and 50th percentile of the annual maximum time series which are associated with a recurrence interval of 10, 5, and 2 years, respectively. According to Table 4, the simulated and observed recurrence intervals are in good agreement, especially for the shorter recurrence intervals. The simulated flows tend to be underestimated at the 90th percentile of AMS, which leads to an overestimation of the 10-year recurrence interval. This is largely due to two factors-the calibration using monthly data and the fact that gridded forcings tend to underestimate precipitation during floods.

Figure 8 shows the return period of all the AMS values (from 1918 to 2011) over each basin. The Brazos River Basin has the largest AMS values for all return periods. This basin has the largest drainage area, and the mean value of AMS 
TABLE 4: Peak flow recurrence interval.

\begin{tabular}{|c|c|c|c|c|c|c|}
\hline \multirow{3}{*}{ Basin } & \multicolumn{6}{|c|}{ Recurrence interval (year) } \\
\hline & \multicolumn{2}{|c|}{ Above 90th percentile of AMS } & \multicolumn{2}{|c|}{ Above 80 th percentile of AMS } & \multicolumn{2}{|c|}{ Above 50th percentile of AMS } \\
\hline & OBS & SIM & OBS & SIM & OBS & SIM \\
\hline SABIN & 9.6 & 10.6 & 4.5 & 4.6 & 2.0 & 2.0 \\
\hline NECHE & 3.3 & 8.8 & 3.9 & 4.8 & 1.8 & 1.9 \\
\hline TRNTY & 6.6 & 8.4 & 2.4 & 2.4 & 2.0 & 1.9 \\
\hline BRAZO & 8.0 & 9.9 & 3.8 & 4.0 & 1.6 & 1.6 \\
\hline COLOR & 9.4 & 9.4 & 3.7 & 3.8 & 1.6 & 1.6 \\
\hline GUADA & 8.0 & 7.6 & 4.4 & 4.4 & 2.0 & 2.0 \\
\hline SANAN & 9.0 & 9.0 & 4.9 & 4.9 & 2.0 & 2.0 \\
\hline NUECE & 9.0 & 10.1 & 4.9 & 5.1 & 2.0 & 2.0 \\
\hline SANJA & 9.0 & 9.6 & 4.5 & 4.8 & 1.9 & 1.9 \\
\hline LAVAC & 9.9 & 9.4 & 4.6 & 4.8 & 2.0 & 2.0 \\
\hline Average & 8.2 & 9.3 & 4.2 & 4.4 & 1.9 & 1.9 \\
\hline
\end{tabular}

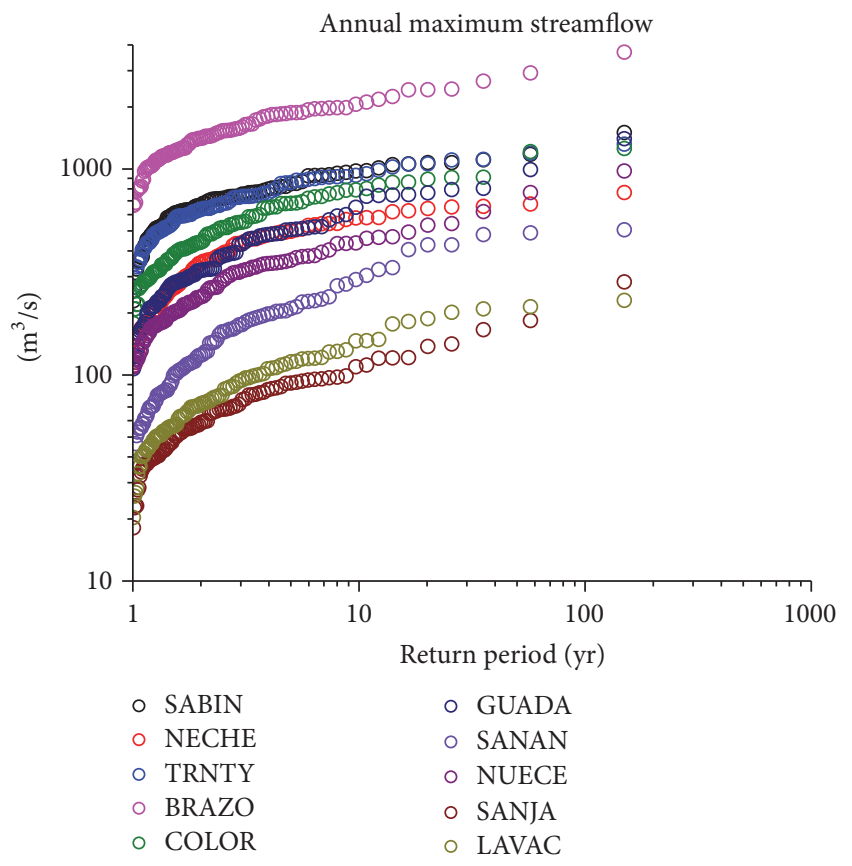

FIGURE 8: Return period of annual maximum streamflow from the simulated streamflow.

$\left(1,482 \mathrm{~m}^{3} / \mathrm{s}\right)$ is nearly two times larger than that of the Sabine Basin (which has the second largest mean AMS at $684 \mathrm{~m}^{3} / \mathrm{s}$ ). The two river basins with the smallest AMS values for a given return period are the San Jacinto and the Lavaca.

\section{Discussion and Summary}

We have produced a model simulated hydrological dataset for the period of 1918-2011 at 1/8 spatial resolution over 10 Texas river basins. Because all of the basins are in juxtaposition, they share similar meteorological conditions. In this way, when one basin suffers drought or flood, the neighboring basins have a good chance of experiencing similar conditions. The basins are correlated, but they are hydrologically independent. Since basin boundaries are delineated according to the Digital Elevation Model (DEM), water from one basin does not naturally move to the neighboring basins, unless there is water management involved (e.g., an interbasin water transfer). When comparing the basins' correlations under extreme conditions, neighboring basins are more likely to experience drought at the same time than flood. This is because droughts usually occur over a large area (due to a lack of precipitation over several months, as shown in Figure 6), while floods have large spatial heterogeneity but short durations.

The simulated streamflow was, for the first time to our knowledge, calibrated and validated against USGS streamflow observations at each basin. Furthermore, the modeled soil moisture results were evaluated against in situ observations. Even though the VIC modeled soil moisture shows wetter conditions than the observed soil moisture, the correlation coefficient and the error values have been improved over previous studies. These reliable and well evaluated results are expected to contribute to water resources management, agricultural planning, and many other related fields in Texas.

In this study, we explored some applications of this new dataset by analyzing changes in water budget terms, and by investigating new perspectives related to hydrological extreme events. The seasonal cycles of the water budget terms are very dynamic for all of the basins, which confirms that the region is prone to both droughts and floods. Overall, the simulated droughts are in good agreement with documented historical droughts. The soil moisture data also provide a basis for better depicturing drought, duration, and many other characteristics-quantitatively-in time and space.

An AMS approach was used to study flooding events. However, because of the intrinsic complexity and short term nature of floods (which occur on a timescale of hours to days), the simulation does not perform as well as it does with droughts. This can be partially attributed to the fact 
that the model calibration was implemented at a monthly time scale to minimize the long-term differences between the observed and simulated streamflow. Therefore, modeling skill in representing daily peak discharge is limited. A daily step, or an event-based calibration, will likely result in an improved dataset for investigating floods (but this would need to be substantiated via another study). Another possible limiting factor (with regard to the use of this dataset for simulating floods) is that reservoir flood control activities were not considered in our simulations. Even though this calibrated model has a limitation with regard to capturing extreme flood events precisely, it can still provide useful information for assisting planning and decision making for future water management activities. Nevertheless, given the fast growth of the state of Texas and the continuously changing climate, this well evaluated dataset may serve as a benchmark for investigating the evolution of hydrological processes and extreme events in the future. For instance, by driving the calibrated model in this study with multiple future scenarios available from the Coupled Model Intercomparison Project Phase 5 (CMIP5) - which has projections until 2099 and the same spatial resolution as the VIC model-streamflow under a changing climate in these basins can be projected.

\section{Competing Interests}

The authors declare that they have no competing interests.

\section{Acknowledgments}

This study was performed under the sponsorships of the US National Science Foundation Grant CBET-1454297 and the Collaborative Research Grant Program from Texas A\&M University and the Consejo Nacional de Ciencia y Tecnologia (TAMU-CONACYT 2014-028). Kyungtae Lee is partially sponsored by the Mills Scholarship 2015-16 from the Texas Water Resources Institute. Maoyi Huang is supported by the Integrated Assessment Research program through the Integrated Multi-Sector Multi-Scale Modeling Scientific Focus Area sponsored by the Biological and Environmental Research Division, Office of Science, US Department of Energy. PNNL is operated by Battelle Memorial Institute for the US Department of Energy under Contract DE-AC0576RLO1830. The authors thank Dr. Do Hyuk Kang from the NASA Goddard Space Flight Center, who gave them technical suggestions about the model. The authors also thank Dr. Ben Livneh from the Cooperative Institute for Research in Environmental Sciences (CIRES), University of Colorado, who provided the long-term hydrologic datasets as a baseline.

\section{References}

[1] T. J. Larkin and G. W. Bomar, Climatic Atlas of Texas, vol. 3, Texas Department of Water Resources, 1983.

[2] B. Guerrero, "The impact of agricultural drought losses on the Texas economy, 2011," Briefing Paper, AgriLife Extension, 2012.

[3] C. S. Gleaton and C. G. Anderson, Facts about Texas and US Agriculture, Texas Cooperative Extension Department of
Agricultural Economics, The Texas A\&M University System, College Station, Tex, USA, 2005.

[4] D. N. Fernando, K. C. Mo, R. Fu et al., "What caused the spring intensification and winter demise of the 2011 drought over Texas?" Climate Dynamics, pp. 1-14, 2016.

[5] R. M. Rauber, J. E. Walsh, and D. J. Charlevoix, Severe and Hazardous Weather, Kendall/Hunt, 2008.

[6] S. D. Schubert, M. J. Suarez, P. J. Pegion, R. D. Koster, and J. T. Bacmeister, "Causes of long-term drought in the U.S. great plains," Journal of Climate, vol. 17, no. 3, pp. 485-503, 2004.

[7] R. Seager, Y. Kushnir, C. Herweijer, N. Naik, and J. Velez, "Modeling of tropical forcing of persistent droughts and pluvials over western North America: 1856-2000," Journal of Climate, vol. 18, no. 19, pp. 4065-4088, 2005.

[8] FEMA, National Mitigation Strategy; Partnerships for Building Safer Communities. Mitigation Directorate, Federal Emergency Management Agency, Washington, DC, USA, 1995.

[9] D. A. Wilhite, M. D. Svoboda, and M. J. Hayes, "Understanding the complex impacts of drought: a key to enhancing drought mitigation and preparedness," Water Resources Management, vol. 21, no. 5, pp. 763-774, 2007.

[10] J. W. Nielsen-Gammon, “The 2011 Texas drought," Texas Water Journal, vol. 3, no. 1, pp. 59-95, 2012.

[11] X. Dong, B. Xi, A. Kennedy et al., "Investigation of the 2006 drought and 2007 flood extremes at the Southern Great Plains through an integrative analysis of observations," Journal of Geophysical Research Atmospheres, vol. 116, no. 3, 2011.

[12] C. G. Collier, "Flash flood forecasting: what are the limits of predictability?" Quarterly Journal of the Royal Meteorological Society, vol. 133, no. 622, pp. 3-23, 2007.

[13] T. Funk, "Heavy convective rainfall forecasting: a look at elevated convection, propagation, and precipitation efficiency," in Proceedings of the 10th Severe Storm and Doppler Radar Conference, Des Moines, Iowa, USA, March 2006.

[14] M. W. Downton, J. Z. B. Miller, and R. A. Pielke Jr., "Reanalysis of U.S. National Weather Service flood loss database," Natural Hazards Review, vol. 6, no. 1, pp. 13-22, 2005.

[15] H. O. Sharif, T. Jackson, M. Hossain, S. B. Shafique, and D. Zane, "Motor vehicle-related flood fatalities in Texas,19592008," Journal of Transportation Safety and Security, vol. 2, no. 4, pp. 325-335, 2010.

[16] H. O. Sharif, T. L. Jackson, M. M. Hossain, and D. Zane, "Analysis of flood fatalities in texas," Natural Hazards Review, vol. 16, no. 1, Article ID 4014016, 2015.

[17] C. M. Goodess, "How is the frequency, location and severity of extreme events likely to change up to 2060?" Environmental Science \& Policy, vol. 27, S1, pp. S4-S14, 2012.

[18] G. Luber and M. McGeehin, "Climate change and extreme heat events," American Journal of Preventive Medicine, vol. 35, no. 5, pp. 429-435, 2008.

[19] K. E. Trenberth, J. T. Fasullo, and T. G. Shepherd, "Attribution of climate extreme events," Nature Climate Change, vol. 5, no. 8, pp. 725-730, 2015.

[20] G. Zhao, H. Gao, and L. Cuo, "Effects of urbanization and climate change on peak flows over the San Antonio River Basin, Texas," Journal of Hydrometeorology, vol. 17, no. 9, pp. 2371-2389, 2016.

[21] R. A. Wurbs and R. A. Ayala, "Reservoir evaporation in Texas, USA," Journal of Hydrology, vol. 510, pp. 1-9, 2014.

[22] Y. Xia, M. B. Ek, C. D. Peters-Lidard et al., "Application of USDM statistics in NLDAS-2: optimal blended NLDAS drought 
index over the continental United States," Journal of Geophysical Research Atmospheres, vol. 119, no. 6, pp. 2947-2965, 2014.

[23] E. Etienne, N. Devineni, R. Khanbilvardi, and U. Lall, "Development of a Demand Sensitive Drought Index and its application for agriculture over the conterminous United States," Journal of Hydrology, vol. 534, pp. 219-229, 2016.

[24] Z. Hao, F. Hao, Y. Xia et al., "A statistical method for categorical drought prediction based on NLDAS-2," Journal of Applied Meteorology and Climatology, vol. 55, no. 4, pp. 1049-1061, 2016.

[25] B. Livneh and M. P. Hoerling, "The physics of drought in the U.S. central great plains," Journal of Climate, vol. 29, no. 18, pp. 6783-6804, 2016.

[26] N. S. Christensen and D. P. Lettenmaier, "A multimodel ensemble approach to assessment of climate change impacts on the hydrology and water resources of the Colorado River Basin," Hydrology and Earth System Sciences, vol. 11, no. 4, pp. 1417-1434, 2007.

[27] N. S. Christensen, A. W. Wood, N. Voisin, D. P. Lettenmaier, and R. N. Palmer, "The effects of climate change on the hydrology and water resources of the Colorado River basin," Climatic Change, vol. 62, no. 1-3, pp. 337-363, 2004.

[28] E. P. Maurer, A. W. Wood, J. C. Adam, D. P. Lettenmaier, and B. Nijssen, "A long-term hydrologically based dataset of land surface fluxes and states for the conterminous United States," Journal of Climate, vol. 15, no. 22, pp. 3237-3251, 2002.

[29] B. Livneh, E. A. Rosenberg, C. Lin et al., "A long-term hydrologically based dataset of land surface fluxes and states for the conterminous United States: update and extensions," Journal of Climate, vol. 26, no. 23, pp. 9384-9392, 2013.

[30] A. A. Oubeidillah, S.-C. Kao, M. Ashfaq, B. S. Naz, and G. Tootle, "A large-scale, high-resolution hydrological model parameter data set for climate change impact assessment for the conterminous US," Hydrology and Earth System Sciences, vol. 18, no. 1, pp. 67-84, 2014.

[31] T. M. Kimmel, J. Nielsen-Gammon, B. Rose, and H. M. Mogil, "The weather and climate of texas: a big state with big extremes," Weatherwise, vol. 69, no. 5, pp. 25-33, 2016.

[32] S. W. Lyons, "Spatial and temporal variability of monthly precipitation in Texas," Monthly Weather Review, vol. 118, no. 12, pp. 2634-2648, 1990.

[33] G. W. Bomar, Texas Weather, University of Texas Press, 1995.

[34] Bureau of Economic Geology, River Basin Map of Texas, Bureau of Economic Geology, Austin, Tex, USA, 1996.

[35] USDA-NASS, Census of Agriculture, US Department of Agriculture, National Agricultural Statistics Service, Washington, DC, USA, 2007.

[36] Xu Liang, D. P. Lettenmaier, E. F. Wood, and S. J. Burges, "A simple hydrologically based model of land surface water and energy fluxes for general circulation models," Journal of Geophysical Research, vol. 99, no. 7, pp. 14,415-14,428, 1994.

[37] H. Gao, Q. H. Tang, C. R. Ferguson, E. F. Wood, and D. P. Lettenmaier, "Estimating the water budget of major US river basins via remote sensing," International Journal of Remote Sensing, vol. 31, no. 14, pp. 3955-3978, 2010.

[38] I. Haddeland, T. Skaugen, and D. P. Lettenmaier, "Hydrologic effects of land and water management in North America and Asia: 1700-1992," Hydrology and Earth System Sciences, vol. 11, no. 2, pp. 1035-1045, 2007.

[39] B. Nijssen, G. M. O’Donnell, D. P. Lettenmaier, D. Lohmann, and E. F. Wood, "Predicting the discharge of global rivers," Journal of Climate, vol. 14, no. 15, pp. 3307-3323, 2001.
[40] H. Wu, J. S. Kimball, M. M. Elsner, N. Mantua, R. F. Adler, and J. Stanford, "Projected climate change impacts on the hydrology and temperature of Pacific Northwest rivers," Water Resources Research, vol. 48, no. 11, 2012.

[41] F. Zhao, F. H. S. Chiew, L. Zhang, J. Vaze, J.-M. Perraud, and M. Li, "Application of a macroscale hydrologic model to estimate streamflow across Southeast Australia," Journal of Hydrometeorology, vol. 13, no. 4, pp. 1233-1250, 2012.

[42] J. Chang, H. Zhang, Y. Wang, and Y. Zhu, "Assessing the impact of climate variability and human activities on streamflow variation," Hydrology and Earth System Sciences, vol. 20, no. 4, pp. 1547-1560, 2016.

[43] X. Yuan, "An experimental seasonal hydrological forecasting system over the Yellow River basin-part 2: the added value from climate forecast models," Hydrology and Earth System Sciences, vol. 20, no. 6, pp. 2453-2466, 2016.

[44] K. M. Andreadis and D. P. Lettenmaier, "Trends in 20th century drought over the continental United States," Geophysical Research Letters, vol. 33, no. 10, Article ID L10403, 2006.

[45] J. Sheffield, G. Goteti, F. Wen, and E. F. Wood, "A simulated soil moisture based drought analysis for the United States," Journal of Geophysical Research: Atmospheres, vol. 109, no. D24, 2004.

[46] J. Sheffield and E. F. Wood, "Projected changes in drought occurrence under future global warming from multi-model, multi-scenario, IPCC AR4 simulations," Climate Dynamics, vol. 31, no. 1, pp. 79-105, 2008.

[47] S. Shukla and A. W. Wood, "Use of a standardized runoff index for characterizing hydrologic drought," Geophysical Research Letters, vol. 35, no. 2, 7 pages, 2008.

[48] C. Tang and T. C. Piechota, "Spatial and temporal soil moisture and drought variability in the Upper Colorado River Basin," Journal of Hydrology, vol. 379, no. 1-2, pp. 122-135, 2009.

[49] R. Wu and J. L. Kinter III, "Analysis of the relationship of U.S. droughts with SST and soil moisture: distinguishing the time scale of droughts," Journal of Climate, vol. 22, no. 17, pp. 45204538, 2009.

[50] L. Luo, J. Sheffield, and E. Wood, "Towards a global drought monitoring and forecasting capability," in Proceedings of the 33rd NOAA Annual Climate Diagnostics and Prediction Workshop, Lincoln, Neb, USA, October 2008.

[51] J. Sheffield, E. F. Wood, N. Chaney et al., "A drought monitoring and forecasting system for sub-sahara african water resources and food security," Bulletin of the American Meteorological Society, vol. 95, no. 6, pp. 861-882, 2014.

[52] D. R. Cayan, T. Das, D. W. Pierce, T. P. Barnett, M. Tyree, and A. Gershunova, "Future dryness in the Southwest US and the hydrology of the early 21st century drought," Proceedings of the National Academy of Sciences of the United States of America, vol. 107, no. 50, pp. 21271-21276, 2010.

[53] Z. Guo, P. A. Dirmeyer, Z. Z. Hu, X. Gao, and M. Zhao, "Evaluation of the second global soil wetness project soil moisture simulations: 2 . Sensitivity to external meteorological forcing," Journal of Geophysical Research: Atmospheres, vol. 111, no. D22, 2006.

[54] J. Sheffield, M. Pan, E. F. Wood et al., "Snow process modeling in the North American Land Data Assimilation System (NLDAS): 1. Evaluation of model-simulated snow cover extent," Journal of Geophysical Research D: Atmospheres, vol. 108, no. 22, 2003.

[55] D. Lohmann, R. Nolte-Holube, and E. Raschke, "A largescale horizontal routing model to be coupled to land surface parametrization schemes," Tellus, Series A: Dynamic Meteorology and Oceanography, vol. 48, no. 5, pp. 708-721, 1996. 
[56] D. S. Shepard, "Computer mapping: the SYMAP interpolation algorithm," in Spatial Statistics and Models, vol. 40 of Theory and Decision Library, pp. 133-145, Springer, Dordrecht, The Netherlands, 1984.

[57] C. Daly, R. P. Neilson, and D. L. Phillips, "A statistical-topographic model for mapping climatological precipitation over mountainous terrain," Journal of Applied Meteorology, vol. 33, no. 2, pp. 140-158, 1994.

[58] E. Kalnay, M. Kanamitsu, R. Kistler et al., "The NCEP/NCAR 40-year reanalysis project," Bulletin of the American Meteorological Society, vol. 77, no. 3, pp. 437-471, 1996.

[59] P. O. Yapo, H. V. Gupta, and S. Sorooshian, "Multi-objective global optimization for hydrologic models," Journal of Hydrology, vol. 204, no. 1-4, pp. 83-97, 1998.

[60] J. E. Nash and J. V. Sutcliffe, "River flow forecasting through conceptual models part I-a discussion of principles," Journal of Hydrology, vol. 10, no. 3, pp. 282-290, 1970.

[61] E. M. Demaria, B. Nijssen, and T. Wagener, "Monte Carlo sensitivity analysis of land surface parameters using the Variable Infiltration Capacity model," Journal of Geophysical Research Atmospheres, vol. 112, no. 11, Article ID D11113, 2007.

[62] T. W. Ford and S. M. Quiring, "Influence of MODIS-derived dynamic vegetation on VIC-simulated soil moisture in oklahoma," Journal of Hydrometeorology, vol. 14, no. 6, pp. 1910-1921, 2013.

[63] H. Gao, E. F. Wood, T. J. Jackson, M. Drusch, and R. Bindlish, "Using TRMM/TMI to retrieve surface soil moisture over the southern United States from 1998 to 2002," Journal of Hydrometeorology, vol. 7, no. 1, pp. 23-38, 2006.

[64] Texas State Library and Archives Commission, Major Droughts in Modern Texas, Texas State Library and Archives Commission, Austin, Tex, USA, 2016.

[65] M. Waldron, "Rains ease year-long Texas drought," The New York Times Archives, vol. 59, 1971.

[66] W. C. Palmer, Meteorological Drought, US Department of Commerce, Weather Bureau, Washington, DC, USA, 1965.

[67] M. P. Peters, L. R. Iverson, and S. N. Matthews, "Long-term droughtiness and drought tolerance of eastern US forests over five decades," Forest Ecology and Management, vol. 345, pp. 5664, 2015.

[68] A. Dai, K. E. Trenberth, and T. Qian, "A global dataset of Palmer Drought Severity Index for 1870-2002: relationship with soil moisture and effects of surface warming," Journal of Hydrometeorology, vol. 5, no. 6, pp. 1117-1130, 2004.

[69] V. Lakshmi, T. Piechota, U. Narayan, and C. Tang, "Soil moisture as an indicator of weather extremes," Geophysical Research Letters, vol. 31, no. 11, 2004.

[70] J. Sheffield and E. F. Wood, "Characteristics of global and regional drought, 1950-2000: analysis of soil moisture data from off-line simulation of the terrestrial hydrologic cycle," Journal of Geophysical Research Atmospheres, vol. 112, no. 17, 2007.

[71] C.-T. Chen and T. Knutson, "On the verification and comparison of extreme rainfall indices from climate models," Journal of Climate, vol. 21, no. 7, pp. 1605-1621, 2008.

[72] M. Gervais, L. B. Tremblay, J. R. Gyakum, and E. Atallah, "Representing extremes in a daily gridded precipitation analysis over the United States: impacts of station density, resolution, and gridding methods," Journal of Climate, vol. 27, no. 14, pp. 5201-5218, 2014.

[73] V. T. Chow, D. R. Maidment, and L. W. Mays, Applied Hydrology, McGraw Hill, 1988. 

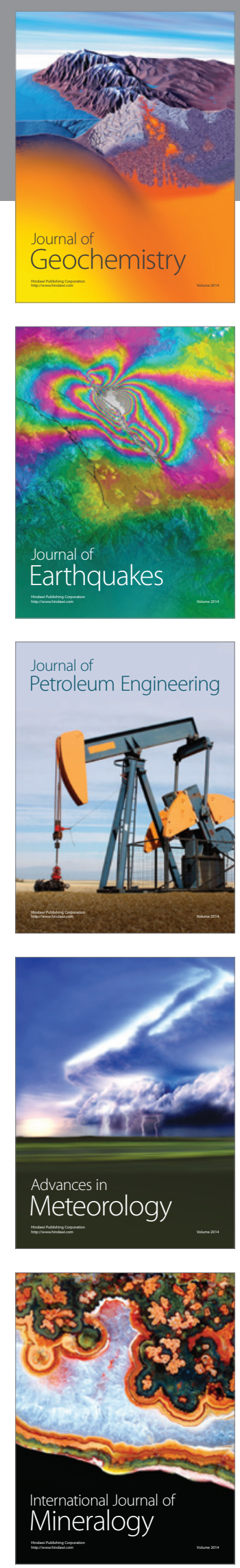
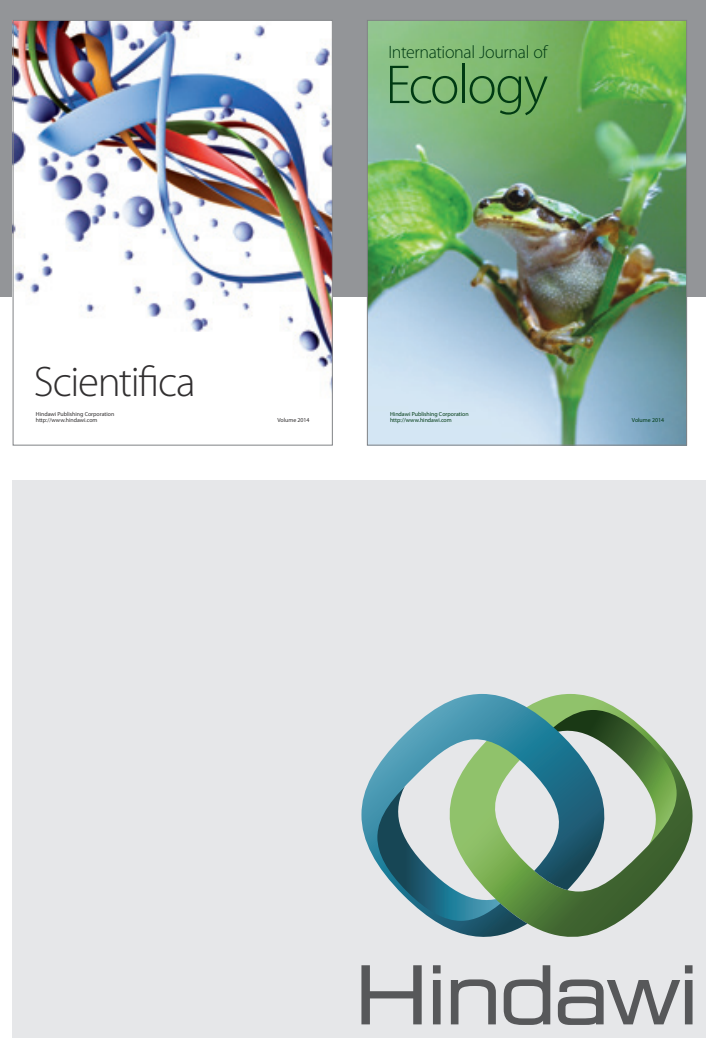

Submit your manuscripts at

https://www.hindawi.com
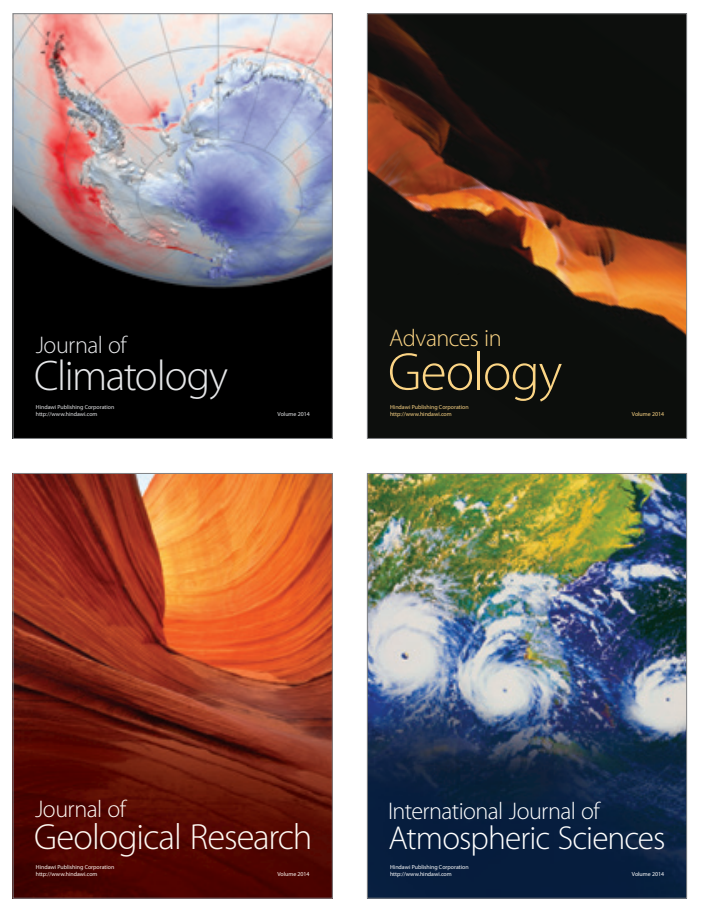

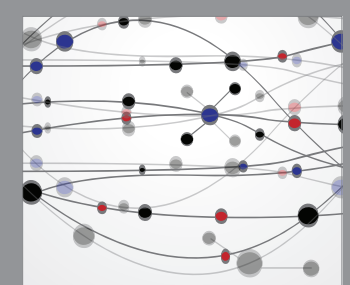

The Scientific

\section{World Journal}
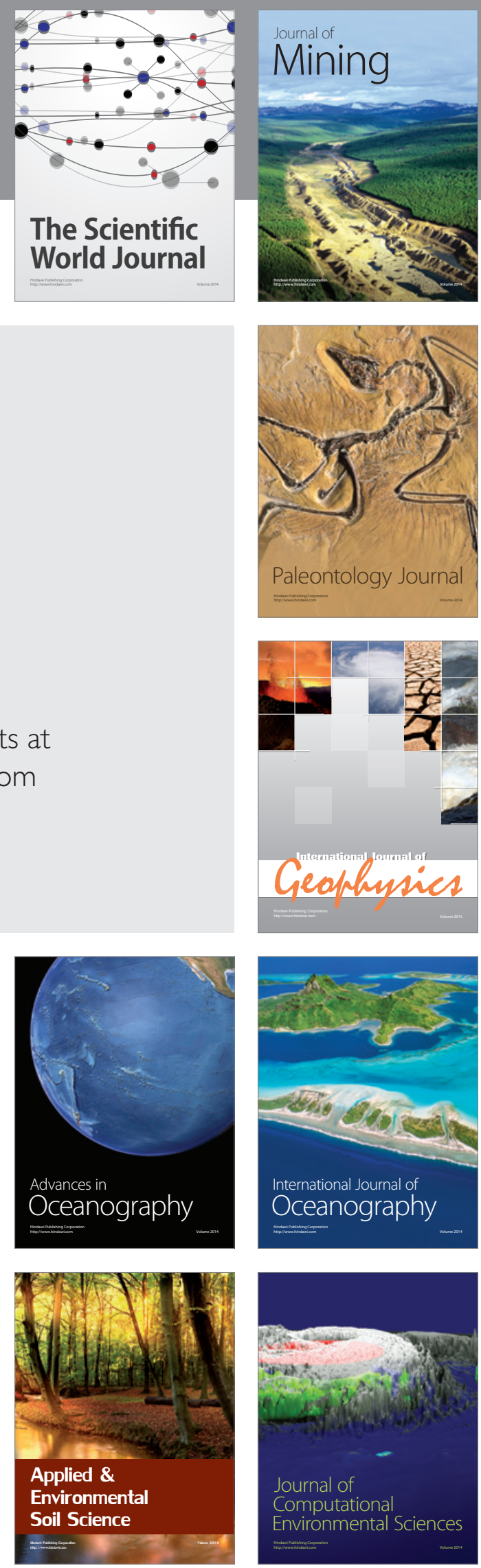